\title{
УДК 351.77:61
}

https://doi.org/10.52058/2786-5274 -2022-2(4)-240-250

Славкова Олена Павлівна доктор економічних наук, професор, завідувач кафедрою публічного управління та адміністрування, Сумський національний аграрний університет, вул. Г. Кондратьєва, м. Суми, 40021, тел.: (044) 264-52-54, https://orcid.org/0000-0002-1864-0810

Соколов Микола Олександрович доктор економічних наук, професор, професор кафедри публічного управління та адміністрування, Сумський національний аграрний університет, вул. Г. Кондратьєва, м. Суми, 40021, тел.: (044) 264-52-54, https://orcid.org/0000-0002-1907-9041.

\section{МЕХАНІЗМИ ДЕРЖАВНОЇ ВЗАСМОДІЇ В НАДАННІ ЯКІСНИХ МЕДИЧНИХ ПОСЛУГ ЛІКУВАЛЬНИМИ ЗАКЛАДАМИ}

Анотація. У статті досліджено сучасний етап розвитку системи охорони здоров’я та механізм дії медичних організацій та конкретний продукт, який вони виробляють, - медичні послуги, основною метою якої $є$ задоволення потреб людини в цілому та яка полягає у відновленні, збереженні та поліпшенні здоров'я населення. Досліджено людський фактор, який відіграє ключову роль у виробництві медичних послуг, оскільки неможливо виключити живу працю медичних працівників. Проаналізовано наукові праці щодо модернізації системи надання медичних послуг, включаючи послуги, що підлягають відшкодуванню, в контексті державно-приватного партнерства, що особливо важливо в умовах недостатньої економічної ефективності в державному секторі охорони здоров'я, обмежених ресурсів громадян та браку персоналу. Розробка механізмів державно-приватного партнерства та участі громадян у фінансовому забезпеченні медичної допомоги 3 використанням ресурсів, не передбачених програмою державних гарантій, $\epsilon$ найважливішим інструментом вирішення багатьох соціально - економічних проблем в охороні здоров’я.

Визначено, що набуття комунальними некомерційними лікувальними установами підприємницького статусу закладу охорони здоров'я створило низку нових ризиків та рішень для цих установ. Встановлено, що аналіз фінансового стану $є$ першим кроком до досягнення фінансової ефективності існування. В умовах моделі інноваційного розвитку важливу роль в управлінні діяльністю лікарні відіграє розуміння сутності та правильної оцінки механізмів державної взаємодії в наданні якісних медичних послуг. Вважаємо, що інноваційний розвиток дозволять керівництву оцінити реальну здатність лікарні реалізувати програму перспективного розвитку як на етапі вибору нової послуги, так і на етапі впровадження. 
В даному дослідженні проведений комплексний аналіз управління системою надання якісних медичних послуг. Він дозволив сформувати науково-обгрунтовані пропозиції та рекомендації щодо удосконалення механізму державної взаємодії в наданні якісних медичних послуг лікувальними закладами.

Зроблено висновок, що належне застосування механізмів державноприватного партнерства разом з іншими механізмами державного регулювання зміцнить економічний i політичний суверенітет України, підвищить іï міжнародний престиж та залучить інвестиції в сферу охорони здоров'я. Доведено, що у центрі уваги подальших досліджень має бути наукова основа застосування механізму державно-приватного партнерства у сфері охорони здоров’я, зокрема надання якісних медичних послуг.

Ключові слова: управління охороною здоров'я, медичні послуги, інновації в управління наданням медичних послуг

Slavkova Olena Pavlivna Doctor of Science in Economy, professor, Head of public management and administration department Sumy National Agrarian University, Herasyma Kondratieva St., 160, Sumy, 40021, тел.: (044) 264-52-54, https://orcid.org/0000-0002-1864-0810

Sokolov Nikolay Oleksandrovuch Doctor of Science in Economy, professor, professor of public management and administration department Sumy National Agrarian University, Herasyma Kondratieva St., 160, Sumy, 40021, тел.: (044) 264-52-54, https://orcid.org/0000-0002-1907-9041.

\title{
MECHANISMS OF STATE INTERACTION IN PROVIDING QUALITY MEDICAL SERVICES TO MEDICAL INSTITUTIONS
}

\begin{abstract}
The article examines the current stage of development of health care and the mechanism of action of medical organizations and the specific product they produce medical services, the main purpose of which is to meet human needs in general and which is to restore, maintain and improve public health. The human factor, which plays a key role in the production of medical services, as it is impossible to exclude the living work of medical workers, has been studied. Scientific works on modernization of the medical services system are analyzed, including reimbursable services in the context of publicprivate partnerships, which is particularly important in the context of insufficient economic efficiency in the public health sector, limited resources of citizens (significant discrimination of income among different segments of the population) and lack of staff. The development of public-private partnership mechanisms and the participation of citizens in the financial provision of health care using resources not provided for in the program of state guarantees is the most important tool for solving many socio-economic problems in health care.
\end{abstract}


It is determined that the acquisition of business status of health care institutions by municipal non-profit medical institutions has created a number of new risks and solutions for these institutions. It is established that the analysis of financial condition is the first step towards achieving financial efficiency of its existence. Under the model of innovative development, an important role in managing the activities of the hospital is played by understanding the nature and correct assessment of the mechanisms of state interaction in the provision of quality medical services. We believe that innovative development and implementation will allow management to assess the real ability of the hospital to implement a program of innovative development both at the stage of choosing a new service and at the stage of implementation.

The complex analysis of the management system of quality medical services is conducted in this research. The conducted analysis allowed forming scientificallyreasonable suggestions and recommendations in relation to the improvement of mechanism of state cooperation in the grant of quality medical services by curative establishments.

It is concluded that the proper application of public-private partnership mechanisms together with other mechanisms of state regulation will strengthen the economic and political sovereignty of Ukraine, increase its international prestige and attract investment in health care. It has been proved that the focus of further research should be on the scientific basis for the application of the mechanism of publicprivate partnership in the field of health care, in particular the provision of quality medical services.

Keywords: health management, medical services, innovations in the management of medical services.

Постановка проблеми. Охорона здоров'я на сьогодні $\epsilon$ одним iз пріоритетів державної політики України. У дореформений період в більшості переважали адміністративні методи управління, які грунтувалися в основному на широкому розвитку закладів охорони здоров’я $з$ державним фінансуванням. У ринковій економіці цей шлях вичерпав свій потенціал як системи, яка практично не використовує економічний вплив, інструменти та стимули для пошуку нових типів лікарень, альтернативної допомоги, розвитку професійних послуг, розробки нових методів лікування чи впровадження нових методів. В основі цих проблем в основному лежить зростання нерівності в доступі до послуг, погіршенні стану здоров'я, соціальні та, як наслідок, економічні втрати як для населення, так і для держави. Найвагомішим проявом нових тенденцій в управлінні закладами охорони здоров'я $\epsilon$ поява нових шляхів розвитку лікувальних установ організацій та механізмів державної взаємодії в наданні якісних медичних послуг лікувальними закладами. Приватні установи відрізняються від державних більш гнучким управлінням, свободою адміністративних і фінансових рішень. Тим не менш, незалежно від типу закладу, до якого належить лікувальна установа, необхідною умовою його 
існування $є$ активне застосування системи ефективних методів управління, адаптованих до специфіки охорони здоров'я як об'єкта економічного регулювання. Що пов’язано з тим, що без цієї ефективної взаємодії не можуть бути задоволені потреби населення в отриманні якісних медичних послуг.

Наша держава постійно піклується про стан здоров’я своїх громадян. Так у Стратегії сталого розвитку України до 2030 року стратегічною цілю 4 визначено, що метою політики громадського здоров'я $\epsilon$ те, що громадське здоров'я та благополуччя мають бути забезпечені для всіх вікових груп. Основними напрямами реформ $є$ запровадження на національному рівні принципу «здоров'я в усіх державних політиках»; запровадження методики оцінки ризиків для здоров'я та довкілля та відшкодування соціальноекономічної шкоди, завданої життю та здоров'ю людей на рівні особистості та населення; очікувана тривалість життя при народженні має бути забезпечена на рівні $\mathrm{CC}$; забезпечення загального охоплення медичними послугами та захист від фінансових ризиків, доступ до якісних базових медичних послуг та безпечних, високоякісних та недорогих основних ліків та вакцин для всього населення [1].

Враховуючи процеси реформування в сфер охорони здоров’я та державної політики щодо удосконалення механізмів іiі реалізації в частині застосування розвитку механізмів державної взаємодії щодо надання якісних медичних послуг вважаємо за необхідним розглянути ці питання в нашій науковій праці.

Аналіз останніх досліджень і публікацій. Окремі аспекти рівнів державної взаємодії в наданні якісних медичних послуг лікувальними закладами були досліджені такими дослідниками як: Дзюндзюк В. Б., Жаліло Л. І., Коротич О. Б., Мартинюк О. І., Мельтюхова Н. М., Миронова Н. М., Одінцова Г. С., Солоненко I. М., Шегедин Я., Яковенко I. та іншими. Незважаючи на достатню кількість публікацій питання щодо удосконалення механізму державної взаємодії в наданні якісних медичних послуг лікувальними закладами досліджені не в повному обсязі.

Мета статті - метою дослідження є комплексний аналіз управління системою надання якісних медичних послуг, формування науково-обгрунтованих пропозицій та рекомендацій щодо удосконалення механізму державної взаємодії в наданні якісних медичних послуг лікувальними закладами.

При написанні наукової статті нами було використано наступні методи дослідження, а саме: метод аналізу та синтезу - при дослідженні думки науковців щодо механізму державної взаємодії в наданні якісних медичних послуг лікувальними закладами; метод економіко-статистичного аналізу та порівняння - при розрахунках показників роботи лікувальної установи; метод узагальнення - при формуванні науково-обгрунтованих пропозицій та рекомендацій щодо удосконалення механізму державної взаємодії в наданні якісних медичних послуг лікувальними закладами. 
Виклад основного матеріалу. Дослідження питань ролі механізмів державної взаємодії в наданні якісних медичних послуг в лікувальних закладах $\epsilon$ актуальним питанням для наукових досліджень, особливо в умовах медичної реформи, яка впроваджується в нашій країні. Ця тема постійно знаходиться в полі зору науковців та викликає жваву дискусію. В даній публікації ми зробимо спробу охарактеризувати дослідження науковців з цієї тематики та накреслити основні напрями удосконалення ролі механізмів державної взаємодії в наданні якісних медичних послуг в лікувальних закладах.

Більшістю вченими механізми державного управління трактуються як «способи вирішення суперечностей явища чи процесу в державному управлінні, послідовне здійснення дій на основі принципів, цілеспрямованості, функціональної діяльності з використанням відповідних управлінських форм $\mathrm{i}$ методів, Так Одінцова Г. С визначає взаємодію суб'єкта і об'єкта, єдність діяльності і відносин, функціонування даної системи чи підсистеми, а також взаємозв'язок між явищами, діями та заходами, результатом яких є узгодження та реалізація інтересів, цілей, рішень з державними ресурсами (владою, апарат, засоби та методи управління)» [2]. До останнього, крім власне механізмів державного управління належать на думку автора механізми регулювання, які реалізуються через певні регуляторні заходи органів влади з метою впливу на ціну, кількість, структуру та якість послуг системи охорони здоров'я.

Такі українські дослідники як Л. Жаліло, О. та І. Мартинюк і I. Солоненко під механізмами державного управління у сфері охорони здоров'я розуміють сукупністю форм, методів, інструментів, можливостей, стимулів, інструментів, за допомогою яких державне управління та регулювання в більшості переважають у сфері охорони здоров'я. Ці ж дослідники сферу охорони здоров'я визначають як взаємодію політичних, економічних, правових, соціально-культурних та ідеологічних факторів, що залежить від цілей i завдань, які ставить держава стосовно охорони здоров'я населення. Це визначення відображає взаємозв'язки та взаємодію між потребами, інтересами та стимулами суб'єктів у цій сфері і рівнем соціально-економічного розвитку країни у конкретних наборах методів, засобів та інструментів [3].

Шегедіним Я. будо проведено наукове дослідження результатами якого було визначення автором низки положень, а саме: політика охорони здоров'я $\epsilon$ невід'ємною частиною політики держави, яка являє собою організований набір цілей, принципів і функцій, механізмів, методів та інструментів; автором визначено, що за допомогою правових та організаційних механізмів завдання 3 організації та контролю процесів охорони здоров'я виконують компетентні органи державної влади, органи місцевого самоврядування та інститути громадянського суспільства; діють механізми реалізації політики громадської опіки на регіональному рівні, послідовні та скоординовані дії органів державної влади та місцевого самоврядування, а також інститутів громадянського суспільства, заснованих на принципах, цілях, функціональній безпеці, 3 
використанням відповідних форм і методів якісної допомоги та регулювання [4, 5].

У науковій літературі партнерство держави, бізнесу та інститутів громадянського суспільства визначається по-різному: існують такі поняття, як «державно-приватне партнерство» та «приватно-державне партнерство». Багато вчених використовують ці терміни як синоніми, відповідні англійському терміну «Public Private Partnership», пояснюючи це особливістю перекладу зарубіжних джерел. Однак все більше авторів розглядають «державно-приватне партнерство» та «приватне-державне партнерство» як певні взаємовиключні поняття, використання яких пов'язано 3 роллю i функціями держави в суспільстві. Істотне використання цих концепції залежить від моделі та культури державного управління. На всіх рівнях управління встановлюється партнерство між державними установами, приватним сектором, до якого входять інвестори та бізнес і представники громадянського суспільства для вирішення соціально важливих питань, що належать до компетенції держави, та отримання взаємних економічних вигод. Державний партнер концентрується на прийнятті необхідних нормативних актів, визначає цілі та завдання проектів державно-приватного партнерства, якість послуги, цінову політику, контролює виконання проектів, тобто виконує регулюючі та координаційні функції. Приватний партнер реалізує проект безпосередньо: він інвестує капітал або використовує навички збору коштів, технічні знання та забезпечує ефективну реалізацію проектів. Послуги третіх сторін також важливі, оскільки місцеві жителі, як представники громадянського суспільства, краще розуміють свої потреби, ніж хтось інший, і шукають шляхи вирішення проблем, пропонуючи державні та приватні сектори партнерства та проектів. Зміст поняття "державно-приватне партнерство" базується на активній позиції громадянського суспільства та приватного сектору у реалізації проектів. Необхідно відмітити, що деякими науковцями були проведені дослідження щодо модернізації системи надання медичних послуг, включаючи послуги, що підлягають відшкодуванню, в напрямку державно-приватного партнерства, що особливо важливо в контексті недостатньої економічної ефективності в державному секторі охорони здоров'я, обмежених ресурсів громадян (відчутна дискримінація доходів у різних верств населення та зниження доходів громадян в умовах пандемії COVID-19) та брак персоналу. Розробка механізмів державно-приватного партнерства та участі громадян (співфінансування) у фінансовому забезпеченні медичної допомоги 3 використанням ресурсів, не передбачених програмою державних гарантій, є найважливішим інструментом вирішення багатьох соціально - економічних проблем в охороні здоров'я [6].

Контроль якості медичних послуг $\epsilon$ одним 3 пріоритетів державної політики, тому для нього залишається важливим питанням «децентралізації» системи охорони здоров'я 3 боку органів місцевого самоврядування та самоуправління. Це посилює роль місцевих громад, але багато питань залишаються актуальними, особливо фінансування. Так, зокрема проблемними 
питаннями залишаються: періодичне відвідування місцевих закладів охорони здоров'я людьми похилого віку; матеріально незабезпечених реабілітаційнолікувальних циклів, які не входять до гарантованого пакету медичних послуг i тому оплачуються; не окреслено обов'язки органів місцевої влади щодо моніторингу та протидії епідеміям; акції вакцинації, особливо дітей; паліативної допомоги невиліковним хворим. Так на думку Яковенко I. роль та механізми надання первинної медико-санітарної допомоги, охорони здоров'я та паліативної допомоги об’єднаними територіальними громадами на даний момент не визначено [7].

Очевидно, що в першу чергу державні та комунальні медичні закладипотребують додаткового фінансування, 3 іншого боку, приватним медичним організаціям потрібно збільшити попит і задоволеність споживачів (пацієнтів), а також фінансові показники медичної організації, тобто збільшити постійний потік пацієнтів. Результатом цього процесу стане неминуче розширення обсягу медичних послуг, що повинно мати позитивний вплив як на попит і задоволеність споживачів (пацієнтів), так і на фінансові результати діяльності медичної організації та ціну медичних послуг.

В якості надання медичних послуг одне 3 першочергових місць займає перехід до інноваційних інформаційних технологій, як однієї 3 моделей державно-приватного партнерства. Так бельгійські вчені розглядають можливість отримання цифрового доступу до, так званих, цифрових пристроїв у рамках проектів державно-приватного партнерства у галузі охорони здоров'я. Під цифровими засобами мається на увазі об'єкти, які мають електронну форму та мають економічну цінність, i які не обов'язково кваліфікуються як громадянські права [8]. Така модель має на меті забезпечити діяльність певних закладів охорони здоров'я та інших суб'єктів медичної інфраструктури справедливо відмічає А.С. Королков [9]. Сюди входить можливість приватних компаній створювати IT-рішення під ключ для медичних організацій, беручи до уваги встановлені цілі загальної інформатизації та розвитку телемедичних технологій. Фактично можна зробити висновок, що партнерські відносини між державними органами та приватними організаціями у галузі охорони здоров'я, включаючи механізми концесій та державно-приватного партнерства, кардинально модернізують маркетингову концепцію виробника (виконавця) медичних послуг. На сьогоднішній день популярною моделлю розвитку державно-приватного партнерства в Україні є залучення приватних медичних організацій до системи охорони здоров'я. Але цей процес тільки почався та потребує удосконалення механізмів реалізації та нормативної бази. Є окремі фактори, які перешкоджають участі приватних медичних організацій у реалізації надання медичних послуг населенню. А саме, на думку С.А. Нефедової, до них можна віднести:

1. Однорічні практики укладання контракту на поставку ліків за програмою доступні ліки. Заохочення участі комерційних клінік у реалізації 
програми обов'язкового медичного страхування яке має бути продовжено на законодавчому рівні до трьох років, а у випадку приватного партнера для медичної інфраструктури - до п'яти років. Впровадження таких змін зменшує ризик відсутності споживачів медичних послуг протягом періоду окупності.

2. Слабке податкове стимулювання діяльності приватних організацій охорони здоров’я при реалізації проектів державно-приватного партнерства. На думку автора необхідно застосувати механізм податкового стимулювання, а саме податку на майно, земельного податку та інших.

3. У тарифі на обов'язкове медичне страхування відсутній елемент інвестицій. Автор вважає, що придбання медичного обладнання також можна розглядати за рахунок обов'язкового медичного страхування, вартість якого перевищує 100 тис. грн. [10].

Практичним прикладом використання механізмів взаємодії є діяльність Комунального некомерційного підприємства «Клінічна лікарня №5» Сумської міської ради. Так за останні два роки відбулося покращення матеріальнотехнічної бази, а саме в 2019 році на 4644447,58 грн. в 2020 році на 25921496,93 грн. Кошти на поповнення були отримані від НСЗУ - 5017507,0 грн., місцевого бюджету - 17708893,43 грн. та обласного бюджету о 3195096,50 .

Медична установа постійно працює над оновленням своєї матеріальної бази, а саме за кошти міської ради зроблений капітальний ремонт на суму понад 6,5 млн. грн. На виділені 3 місцевого бюджету понад 11 мільйонів гривень, лікарня значно оновила арсенал медичного обладнання. А саме придбано два високопродуктивні рентгенівські апарати (8,5 млн. грн.), комп'ютерну техніку (541,9 тис. грн.), три електрокардіографи (176,2 тис. грн.), 33 кисневі концентратори (1,5 млн. грн.) та інше обладнання для надання послуг для населення. КНП «Клінічна лікарня №5» СМР виграла в останній рік три тендери: послуги у сфері охорони здоров'я різні; послуги у сфері охорони здоров'я на суму 10078 тис. грн.; медичні послуги на суму 209 тис. грн.; медичний огляд працівників ДК 021:2015 85140000-2 - послуги у сфері охорони здоров’я різні (104 особи) на суму 22516 тис. грн.

Лікарня постійно співпрацює 3 місцевою владою. Одним із показових прикладів міцної співпраці 3 усіма гілками влади $є$ розробка системи постачання медичного кисню. Киснева терапія є важливою частиною лікування пацієнтів. Для забезпечення 100\% кисню обладнано кисневу станцію, куди вкладено понад 3,5 млн. грн. Ми вважаємо, що це чудовий приклад спільної роботи, коли кошти лікарні, міської ради, місцевого бізнесу та держбюджету об'єднані за підтримки області для надання якісних медичних послуг. Виходячи з постійної роботи щодо удосконалення своєї роботи сформувалися окремі переваги КНП «Клінічна лікарня №5» і медична установа отримала статус «Підприємство року 2020» від спільноти «Ліга кращих». До них можна віднести: 
- ліцензійні права на використання статусу «Підприємство 2020 року» у власній символіці.

- міжнародний сертифікат «Підприємство року 2020» для використання в міжнародних заявках та програмах співпраці.

- диплом «Підприємство 2020 року», виданий в Україні, засвідчений аудиторами Standard Chartered Rating (Німеччина, СС) та Міжнародної федерації кваліфікацій (Гонконг).

- статус «Підприємство року 2020» має бездоганну ділову репутацію, сертифіковану в Свропейському Союзі.

Аналіз діяльності лікувальної установи показує, що використання механізмів державної взаємодії в наданні якісних медичних послуг лікувальними закладами значно розширюють їх можливості та мають перспективи в подальшому розвитку.

Висновки. Отже, державно-приватне партнерство це сучасний механізм, застосування якого сприятиме розвитку України, значному скороченню видатків 3 державного бюджету України та місцевих бюджетів, особливо в умовах воєнних дій на Сході та економічного розвитку ситуація[11]. Правильне використання механізмів державно-приватного партнерства разом 3 іншими механізмами державного регулювання зміцнить економічний та політичний суверенітет України, підвищить іi міжнародний авторитет та залучить інвестиції. На наш погляд, подальші дослідження повинні зосередитись на наукових засадах застосування механізму державно-приватного партнерства у медичній сфері державної діяльності, зокрема у наданні якісних медичних послуг.

\section{Jimepamypa:}

1. Проект Стратегії сталого розвитку України до 2030 року. URL: https://ips.ligazakon.net / document/ JH6YF00A?an= 338\&lang=ua/

2. Одінцова Г. С., Дзюндзюк В. Б., Мельтюхова Н. М., Миронова Н. М., Коротич О. Б. Механізми державного управління. Енциклопедія державного управління: у 8 т. наук.-ред. кол. : Ю. В. Ковбасюк; НАДУ при Президентові України. К. : НАДУ, 2011. Т. 8: Публічне врядування. наук.-ред. кол. : В. С. Загорський. Львівський регіональний інститут державного управління НАДУ при Президентові України. Львів : ЛРІДУ НАДУ, 2011. 630 с.

3. Жаліло Л. І., Мартинюк О. І., Солоненко І. М. Механізми державного управління у сфері охорони здоров'я. Енциклопедія державного управління : у 8 т. НАДУ при Президентові України ; наук.-ред. кол. : Ю. В. Ковбасюк. Т. 2 : Методологія державного управління. наук.-ред. кол. : Ю. П. Сурмін. К. : НАДУ, 2011. 630с.

4. Шегедин Я. Правовий та організаційний механізми реалізації на регіональному рівні державної політики в галузі медсестринства. Ефективність державного управління. 2017. вип. 2 (51). ч. 1. С.129-137.

5. Шегедин Я. Державна політика в галузі медсестринства: структурнофункціональний аспект. Демократичне врядування : наук. вісн. ЛРІДУ НАДУ. 2017. № 18/19. URL : http://www.lvivacademy.com/vidavnitstvo_1/visnyk18/ index.html. 
6. Кадыров Ф. М. Возможные варианты соучастия граждан в финансовом обеспечении оказания медицинской помощи по использованию ресурсов, не предусмотренных программой госгарантий. Менеджер здравоохранения. 2017. № 5. С. 70-76.

7. Яковенко I. Реформа системи охорони здоров'я: чотири напрямки. URL : http:// www. segodnya. ua/ opinion/yakovenkocolumn/reforma-sistemi-ohoroni-zdorovya-chotirina prya mki -760222.html.

8. Aartsen W, Peeters P, Wagers S, Williams-Jones B. Getng Digital Assets from Public-Private Partnership Research Projects through "The Valley of Death," and Making Them Sustainable. Front Med (Lausanne). 2018 Mar 9;5:65. URL: https://pubmed.ncbi.nlm.nih.gov/29594123/.

9. Корольков А. С. Совершенствование офтальмологической помощи городскому населению в условиях развития государственно-частного взаимодействия. Дисс. ... канд. мед. наук. Ставрополь, 2016. 19 с.

10. Нефедова С. А. Участие частных медицинских организаций в реализации программы государственных гарантий бесплатного оказания гражданам медицинской помощи как механизм государственно частного взаимодействия в сфере здравоохранения. URL: file:///D:/Downloads/uchastie-chastnyh-meditsinskih-organizatsiy-vrealizatsii-programmygosudarstvennyh-garantiy-besplatnogo-okazaniya-grazhdanam-meditsinskoypomoschi-kakmehanizm-gosudarstvenno-chastnogo-vzaimodeystviya-v-sfere-zdravoohraneniya.pdf

11. Соколов М.О., Ткач Т.В. Механізми державної взаємодії в наданні якісних медичних послуг лікувальним закладом. Модернізація економіки: сучасні реалії, прогнозні сценарії та перспективи розвитку: матеріали міжнар. наук.-практ. конф. (28-29 квітня 2021 р., м. Херсон). Херсон: Видавництво ФОП Вишемирський В.С., 2021. С. 227-229.

\section{References:}

1. Proekt Stratehii staloho rozvytku Ukrainy do 2030 roku [Draft Strategy for Sustainable Development of Ukraine until 2030]. Retrieved from https://ips.ligazakon.net/ document/ JH6YF00A? an= 338\&lang=ua/ [in Ukraine].

2. Odintsova H. S. \& Dziundziuk V. B. \& Meltiukhova N. M. \& Myronova N. M. \& Korotych O. B. (2011) Mekhanizmy derzhavnoho upravlinnia [Mechanisms of public administration]. Entsyklopediia derzhavnoho upravlinnia: u 8 t. Yu. V. Kovbasiuk (Ed). NADU pry Prezydentovi Ukrainy. K. : NADU, T. 8: Publichne vriaduvannia. V. S. Zahorskyi (Ed). Lvivskyi rehionalnyi instytut derzhavnoho upravlinnia NADU pry Prezydentovi Ukrainy. Lviv : LRIDU NADU, 2011. 630 s. [in Ukraine].

3. Zhalilo L. I. \& Martyniuk O. I. \& Solonenko I. M. (2011) Mekhanizmy derzhavnoho upravlinnia u sferi okhorony zdorovia [Mechanisms of public administration in the field of health care] Entsyklopediia derzhavnoho upravlinnia : u 8 t. NADU pry Prezydentovi Ukrainy. Yu. V. Kovbasiuk (Ed). T. 2 : Metodolohiia derzhavnoho upravlinnia. Yu. P. Surmin (Ed). K. : NADU 630s. [in Ukraine].

4. Shehedyn Y. (2017) Pravovyi ta orhanizatsiinyi mekhanizmy realizatsii na rehionalnomu rivni derzhavnoi polityky $\mathrm{v}$ haluzi medsestrynstva [Legal and organizational mechanisms for implementation at the regional level of state policy in the field of nursing] Efektyvnist derzhavnoho upravlinnia, 2 (51), 129-137 [in Ukraine].

5. Shehedyn Y. (2017) Derzhavna polityka v haluzi medsestrynstva: strukturnofunktsionalnyi aspekt [State policy in the field of nursing: structural and functional aspect] Demokratychne vriaduvannia : nauk. visn. LRIDU NADU, 18/19. Retrieved from http://www.lvivacademy.com/vidavnitstvo_1/visnyk18/ index.html. [in Ukraine].

6. Kadurov F. M. (2017) Vozmozhnыe varyantы souchastyia hrazhdan v fynansovom obespechenyy okazanyia medytsynskoi pomoshchy po yspolzovanyiu resursov, ne predusmotrennukh prohrammoi hosharantyi [Possible options for complicity of citizens in the 
financial provision of medical care for the use of resources not provided by the program of state guarantees] Menedzher zdravookhranenyia, 5, 70-76. [in Russian].

7. Iakovenko I. (2016) Reforma systemy okhorony zdorovia: chotyry napriamky [Reform of the health care system: four directions] Retrieved from http:// www. segodnya.ua/opinion/ yakovenkocolumn/reforma-sistemi-ohoroni-zdorovya-chotirina prya mki -760222.html. [in Ukraine].

8. Aartsen W. \& Peeters P. \& Wagers S. \& Williams-Jones B. (2018) Getng Digital Assets from Public-Private Partnership Research Projects through "The Valley of Death," and Making Them Sustainable [Getng Digital Assets from Public-Private Partnership Research Projects through "The Valley of Death," and Making Them Sustainable] Front Med (Lausanne). 9, 5, 65. URL: https://pubmed.ncbi.nlm.nih.gov/29594123/. [in Eglish].

9. Korolkov A. S. (2016) Sovershenstvovanye oftalmolohycheskoi pomoshchy horodskomu naselenyiu $\mathrm{v}$ uslovyiakh razvytyia hosudarstvenno-chastnoho vzaymodeistvyia. [Improving ophthalmic care for the urban population in the development of public-private interaction] Extended abstract of candidate's thesis. Stavropol [in Russian].

10. Nefedova S. A. (2018) Uchastye chastnokh medytsynskykh orhanyzatsyi v realyzatsyy prohrammы hosudarstvennыkh harantyi besplatnoho okazanyia hrazhdanam medytsynskoi pomoshchy kak mekhanyzm hosudarstvenno chastnoho vzaymodeistvyia $v$ sfere zdravookhranenyia [Participation of private medical organizations in the implementation of the program of state guarantees of free medical care to citizens as a mechanism of public-private interaction in the field of health care] Retrieved from file:///D:/Downloads/uchastie-chastnyh-meditsinskih-organizatsiy-v-realizatsii-programmy gosudarstvennyh-garantiy-besplatnogo-okazaniya-grazhdanam-meditsinskoy-pomoschi-kakmehanizmgosudarstvenno-chastnogo-vzaimodeystviya-v-sfere-zdravoohraneniya.pdf [in Russian].

11. Sokolov M.O., Tkach T.V. (2021) Mekhanizmy derzhavnoi vzaiemodii v nadanni yakisnykh medychnykh posluh likuvalnym zakladom [Mechanisms of state interaction in the provision of quality medical services by medical institutions] Modernizatsiia ekonomiky: suchasni realii, prohnozni stsenarii ta perspektyvy rozvytku: materialy mizhnar. nauk.-prakt. konf. (28-29 kvitnia $2021 \mathrm{r} ., \mathrm{m}$. Kherson). Kherson: Vydavnytstvo FOP Vyshemyrskyi V.S., 227-229. [in Ukraine]. 